\title{
The Monoamine-Containing Neurons in the Brain of the Garfish, Lepisosteus osseus
}

\author{
ANDRÉ PARENT AND R. GLENN NORTHCUTT \\ Laboratoire de Neurobiologie et Département d'Anatomie \\ Faculté de Médecine, Université Laval, Québec, GIK 7P4, Canada \\ and Division of Biological Sciences, University of Michigan, Ann Arbor, MI 48109
}

\begin{abstract}
PARENT, A. AND R. G. NORTHCUTT. The monoamine-containing neurons in the brain of the garfish, Lepisosteus osseus. BRAIN RES. BULL. 9(1-6) 189-204, 1982.-The morphological organization of monoamine (MA)-containing neurons in the brain of the longnose gar (Lepisosteus osseus) was studied by means af fluorescence histochemical methods. In this species, one of the few living representatives of the holostean group of actinopterygian fishes, by far the largest number of MA cells is found within the preoptico-hypothalamic complex. Multitudinous small-sized MA cells, with a short club-like process protruding into the third ventricle, are present along the ependymal wall of the lateral and posterior hypothalamic recesses. This population of CSF-contacting MA cells, comprising both catecholamine (CA) and serotonin (5-HT) type cells, gives rise to numerous efferent fibers, some of which proceed rostrally toward the telencephalon while others course dorsally to reach the midbrain tegmentum and optic tectum. Many fibers, however, arborize directly within the hypothalamus, particularly around blood vessels where they form patches of highly fluorescent material. Small CA cells are also scattered along the preoptic recess wall. They do not directly contact the CSF but also appear to contribute to the CA innervation of telencephalon. At brain stem levels, a few CA cells are scattered at the base of the rostral midbrain, in the isthmal tegmentum, and in the central and dorsal (vagal lobe) portions of the medulla. Some CSF-contacting CA cells are also present around the central canal at upper spinal cord levels. One of the most striking features of the MA systems in Lepisosteus is the remarkable development of the 5-HT neuronal network. A prominent 5-HT cell column extends rostrocaudally in the raphe region from the caudal midbrain to upper spinal cord levels. In the caudal midbrain and isthmus, the 5-HT cells also invade the lateral tegmemtum and profusely innervate various brain stem structures as well as large portions of telencephalon, particularly the dorsal nucleus of area ventralis (Vd). The CA innervation of telencephalon is relatively weak, except in the olfactory bulb where numerous CA varicosities were found. These findings in Lepisosteus suggest that the pattern of MA system organization in the holostean brain is far more similar to that seen in primitive vertebrates, such as cyclostomes-where the 5-HT systems are highly elaborated relative to the CA systems-than it is to the pattern in more advanced fishes such as teleosts.
\end{abstract}

Brain monoamine neurons Nonmammalian vertebrates Histofluorescence methods

Comparative neuroanatomy Lepisosteus osseus Holostean fishes

DESPITE the fact that central monoaminergic systems are known to be phylogenetically ancient and are thought to subserve fundamental brain functions in all vertebrates [26], very little is yet known of their anatomical organization in nonmammals. This lack of information is particularly obvious in fishes. Until now, the cellular localization of these putative neurotransmitters has been studied by means of fluorescence histochemical methods in the brains of only a few teleosts among all bony fishes (see Refs. in [27-32]). The teleosts, however, are known to be the most specialized representatives of a broad radiation (actinopterygian radiation) of bony fishes. Hence, a clear picture of the general patterns of organization of the monoaminergic systems in the brain of fishes has not yet emerged.

In contrast to teleosts, chondrosteans (sturgeons and paddlefish) and holosteans (gars and bowfin) are represented by only a few extant species. They are of interest in that their brain organization is more simple than that in teleosts and, therefore, they may serve as a model of the primitive actinopterygian stock [23]. Thus, it was thought of interest to undertake a histofluorescence investigation of the brain of the longnose gar (Lepisosteus osseus), a holostean, in the hope of reaching a greater understanding of the organization of monoamine (MA)-containing neuronal systems in the brains of bony fishes. It was expected, among other things, that such a study in holosteans would reveal important clues as to how the antinopterygian radiation differs from land vertebrates in regard to the arrangement of MA neuronal systems.

\section{METHOD}

A total of 36 specimens of longnose gars, Lepisosteus 


\begin{tabular}{|c|c|c|c|}
\hline A & Auricle of cerebellum & $n X$ & Motor nucleus of vagal nerve \\
\hline $\mathrm{C}$ & Corpus of cerebellum & $\mathrm{OB}$ & Olfactory bulb \\
\hline $\mathrm{CC}$ & Cerebellar crest & $\mathrm{OC}$ & Optic chiasm \\
\hline $\mathrm{CN}$ & Cerebellar nucleus & ON & Olfactory nerve \\
\hline CP & Central posterior thalamic nucleus & $\mathrm{PC}$ & Posterior commisure \\
\hline $\mathrm{D}$ & Area dorsalis telecephalic & PG & Preglomerular complex \\
\hline Dd & Dorsal zone of $\mathrm{D}$ & PP & Periventricular preoptic nucleus \\
\hline DI & Lateral zone of $\mathrm{D}$ & PR & Posterior recess of the third ventricle \\
\hline $\mathrm{Dm}$ & Medial zone of D & $\mathrm{PT}$ & Central pretectal nucleus \\
\hline $\mathrm{Dp}$ & Posterior zone of $\mathrm{D}$ & PV & Periventricular pretectal nucleus \\
\hline DT & Dorsal thalamus & $\mathrm{SC}$ & Spinal cord \\
\hline $\mathrm{ECL}$ & External cell layers of olfactory bulb & SG & Secondary gustatory nucleus \\
\hline FG & Fminentia granularis & $\mathrm{SMC}$ & Spinal motor cells \\
\hline EN & Entopeduncular nucleus & SN & Suprachiasmatic nucleus \\
\hline FN & Funicular nucleus & SOD & Supraoptic decussation \\
\hline FR & Fasciculus retroflexus & SOF & Secondary olfactory fiber layer of olfactory bulb \\
\hline $\mathrm{GL}$ & Glomerular layer of olfactory bulb & SR & Superior raphe nucleus \\
\hline $\mathbf{H}$ & Habenula & $\mathrm{TC}$ & Tela chorioidea \\
\hline HA & Hypophysis, pars anterior & TEC & Optic tectum \\
\hline HP & Hypophysis, pars posterior & TEL & Telencephalon \\
\hline ICL & Internal cell layer of olfactory bulb & $\mathrm{TL}$ & Torus longitudinalis \\
\hline IL & Inferior lobe of hypothalamus & TPP & Periventricular nucleus of posterior tuberculum \\
\hline IP & Interpeduncular nucleus & TS & Torus semicircularis \\
\hline IRN & Inferior reticular nucleus & $\mathrm{V}$ & Area ventralis telencephali \\
\hline LR & Lateral recess of third ventricle & VA & Valvula \\
\hline LT & Lateral tegmental nucleus & $\mathrm{Vd}$ & Dorsal nucleus of $\mathrm{V}$ \\
\hline MC & Mitral cells & VL & Vagal lobe \\
\hline MLF & Medial longitudinal fasciculus & V1 & Lateral nucleus of $\mathrm{V}$ \\
\hline $\mathrm{MN}$ & Magnocellular octavolateralis nucleus & $\mathrm{Vn}$ & 'Nother nucleus of $\mathrm{V}$ \\
\hline MO & medulla oblongata & VOT & Nucleus of ventral optic tract \\
\hline MOL & Medial octavolateralis nucleus & $V p$ & Postcommissural nucleus of $\mathrm{V}$ \\
\hline MR & Medial reticular nucleus & $V T$ & Ventral thalamus \\
\hline $\mathrm{NI}$ & Nucleus isthmi & $\mathrm{Vv}$ & Ventral nucleus of $\mathrm{V}$ \\
\hline NOT & Nucleus of olfactory tract & II & Optic nerve \\
\hline NPT & Nucleus posterior thalami & III & Oculomotor nerve \\
\hline $\mathrm{NT}$ & Nucleus taenia & V-VII & Trigemino-facial complex \\
\hline NTL & Nucleus of torus lateralis & VIII & Octavus nerve \\
\hline NVL & Nucleus ventralis lateralis & IX & Glossopharyngeal nerve \\
\hline nVII & Motor nucleus of facial nerve & $\mathrm{X}$ & Vagus nerve \\
\hline
\end{tabular}

osseus (=Lepidosteus osseus), were used in the present study. The monoamines were visualized histochemically either by means of the standard Falck-Hillarp paraformaldehyde method $[13,14]$ (21 cases), or with the help of the sucrose-potassium phosphate-glyoxylic acid (SPG) procedure $[9,10]$ (15 cases). All the animals (body length ranging from 23 to $35 \mathrm{~cm}$ ) were sacrificed by decapitation and their brains dissected out as rapidly as possible. The brains to be processed according to the Falck-Hillarp histofluorescence method were first frozen in liquid propane, then freeze-dried for a period of five days, and subsequently treated with paraformaldehyde ( $70 \%$ relative humidty) for one hour at $80^{\circ} \mathrm{C}$. The freeze-dried brains were embedded in paraffin in vacuo and sectioned at $10 \mu \mathrm{m}$ in the transverse plane. The other brains were placed in a cryostat and sectioned at 20-30 $\mu \mathrm{m}$ either in the transverse, horizontal or sagittal plane. The brain sections were treated according to the SPG histofluorescence procedure described by de la Torre [9]. The fluorescence microscopy was performed with a Zeiss or a
Leitz microscope, the latter equipped with a Leitz Ploempack-2 system for reflected light microscopy. In addition, complete series of brain sections processed with Bodian, Nissl, Golgi-Cox, and Klüver-Barrera methods and cut in the 3 standard anatomical planes were available for the study of nuclear groups and fiber tracts in Lepisosteus. In the present study no attempt was made to distinguish between norepinephrine and dopamine, as both primary catecholamines yield a similar yellow-green fluorescence after paraformaldehyde treatment.

\section{RESULTS}

The overall distribution of catecholamine (CA)- and serotonin (5-hydroxytryptamine, 5-HT)-containing neurons in the brain of Lepisosteus osseus is illustrated in a series of semi-schematic transverse sections displayed in a caudorostral order (Figs. 2-6). In these figures the nomenclature used for the telencephalon follows that of Nieuwenhuys [21] 


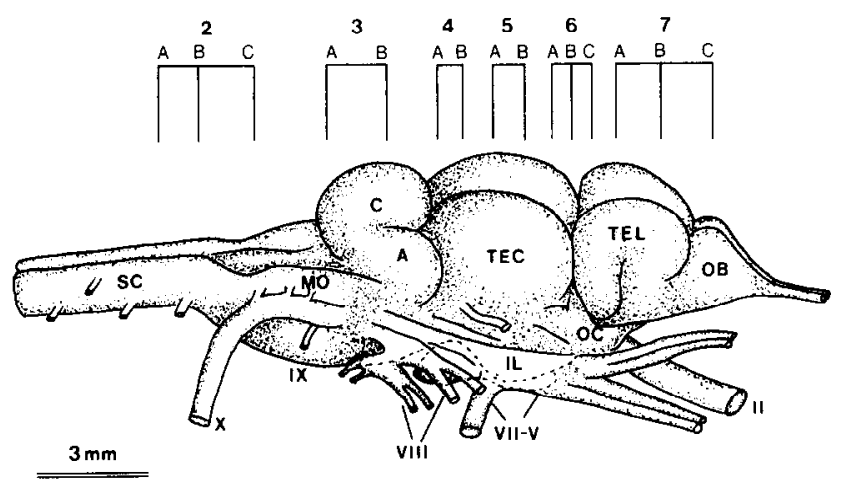

FIG. 1. Lateral view of the brain of the garfish, Lepisosteus osseus. Numbered lines indicate the levels of the transverse sections in Figs. 2 to 7 .

as modified by Northcutt and Braford [22], whereas the nomenclature for the rest of the brain is in general usage (see [3]).

\section{Medulla Oblongata (Figs. 2, 3, 8, 9D)}

Numerous monoamine (MA)-containing cells are present at the level of the junction between the medulla and the spinal cord. First, there are small-sized (mean diameter: $10-15 \mu \mathrm{m})$ CA cells located beneath and partly within the ependymal layer of the central canal (Figs. 2A, 8A, B). They possess a short club-like process protruding directly into the lumen of the central canal. No other process belonging to these CA cells could be visualized. Second, 5-HT neuronal somata occur along the lateral border of, and in between, the medial longitudinal fasciculi (Figs. 2A, 8A). The 5-HT neurons located in between the medial longitudinal fasciculi are mostly bipolar, and their thick and varicose processes are orientated along the vertical axis of the midline. Thesc processes are often seen in close proximity to large midline blood vessels. The 5-HT cells lying along the lateral border of the medial longitudinal fasciculi are slightly larger than the medially located ones. They appear to give rise to a multitude of very fine 5-HT axonal varicosities closely surrounding the neuronal somata of the voluminous spinal motor cells (Fig. 2A, B). Numerous CA axonal varicosities can also be visualized in the lower medulla. They are characteristically larger and more intensely fluorescent than the 5-HT varicosities. The CA varicosities abound in the core (neuropil region) of the so-called funicular nucleus where they are closely packed (Figs. 2A, B; 9D), and along the ventrolateral border of the medulla (Fig. 2).

More rostrally in the medulla oblongata, 5-HT nerve cell bodies are found exclusively within the raphe region (Figs. $2 \mathrm{C}, 3,8 \mathrm{C}$ ), whereas $\mathrm{CA}$ cells occur in the vagal lobe (Figs. $2 \mathrm{C}, 3)$ and within the central portion of the medulla, particularly lateral to the facial motor nucleus (Figs. 3A, 8D). In the vagal lobe the $\mathrm{CA}$ cells are mainly found ventromedially in the caudal half (Fig. 2C) and dorsomedially in the rostral half of this nucleus (Fig. 3). These neurons arc of small size (maximum diameter: $10-15 \mu \mathrm{m}$ ) and appear to give rise to numerous $\mathrm{CA}$ axonal varicosities distributed mainly in the lateral portion of the vagal lobe. The CA neurons lying in the central portion of the medulla are larger (maximum diameter:
20-30 $\mu \mathrm{m}$ ) than those in vagal lobe. They give rise to numerous axonal varicose profiles which accumulate along the ventrolateral border of the medulla. Some of these CA axonal profiles can be seen to cross the midline beneath the bulk of the 5-HT neurons of the raphe region (Fig. 2C).

\section{Isthmus (Figs. 4, 9B)}

The 5-HT nerve cell bodies are strikingly abundant at the isthmal level. They predominate in the raphe region but some of them are also found more laterally in the tegmentum, particularly around the medial longitudinal fasciculi (Fig. 4). These neurons give rise to numerous 5-HT axonal varicosities which accumulate in very large number along the lateral border of the ventricle, in a rather well-circumscribed area corresponding more or less to the so-called cerebellar nucleus (Fig. 4A). This ill-defined periventricular region appears to receive one of the heaviest 5-HT innervations yet disclosed in the Lepisosteus brain (Fig. 9B).

In regard to $\mathrm{CA}$ neurons, a few small-sized CA cells are found in the dorsolateral portion of the isthmal tegmentum, lateral to the secondary gustatory nucleus (Fig. 4A). These are rather weakly fluorescent cells surrounded by numerous brightly fluorescent CA axonal profiles. The latter appear to be part of a complex fiber system consisting of a paramedian and of a more laterally located array of straight CA profiles which course vertically through the isthmal tegmentum. In transverse sections the CA fascicles appear to emerge from the periventricular gray regions bordering both the medial and lateral recesses of the cerebral ventricle (Fig. 4B). However, the exact origin and final destination of the CA axons forming this impressive radiation of fluorescent tegmental fibers remain to be investigated. It is nevertheless worth noting that at the isthmal level the periventricular gray itself contains a multitude of thick CA axonal varicosities often interspersed between the 5-HT cells dorsolaterally surrounding the medial longitudinal fasciculi (Fig. 4B).

\section{Midbrain (Figs. 5, 9A, 9E)}

Nerve cell bodies of the 5-HT type can be found only in the caudal half of the midbrain tegmentum where they closely surround the medial longitudinal fasciculi. Most of them are smaller (maximum diameter: $20 \mu \mathrm{m}$ ) than the more caudally located 5 -HT cells. They can be seen to give rise to fine 5-HT axonal profiles particularly abundant at the periphery of the interpeduncular nucleus (Fig. 9A).

A few isolated and weakly fluorescent CA cells are present at the base of the rostral midbrain tegmentum, medial to the oculomotor nerve root fibers (Fig. 5A). Despite the scarcity of CA neuronal somata in the midbrain proper, numerous thick CA axonal varicosities are found in various mesencephalic structures such as the nucleus of the torus lateralis (Figs. 5, 9E), the torus semicircularis (Fig. 5), the lateral tegmental nucleus (Fig. 5A), and the optic tectum (Figs. 4, 5, 6A). In the optic tectum the $\mathrm{CA}$ varicosities are especially numerous in the stratum periventriculare where most of them closely surround the cell bodies of tectal neurons (Figs. 4, 5).

Diencephalon (Figs. 5, 6, 7A, 10)

The vast majority of the MA-containing cells in the brain of Lepisosteus are found within the preoptico-hypothalamic complex. At hypothalamic levels there is a multitude of small bipolar cells (maximum diameter: $10 \mu \mathrm{m}$ ) of both CA and 
A

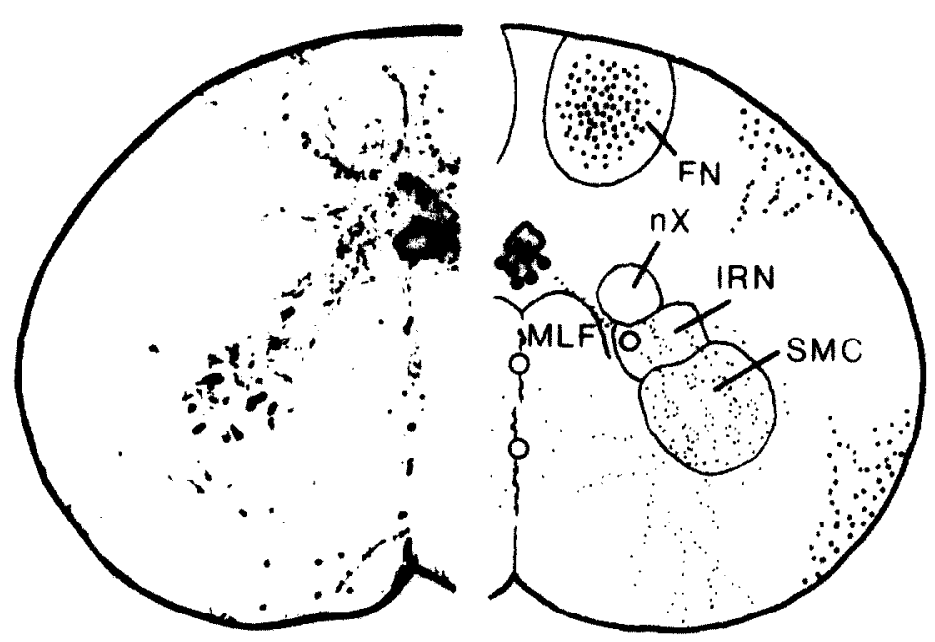

B
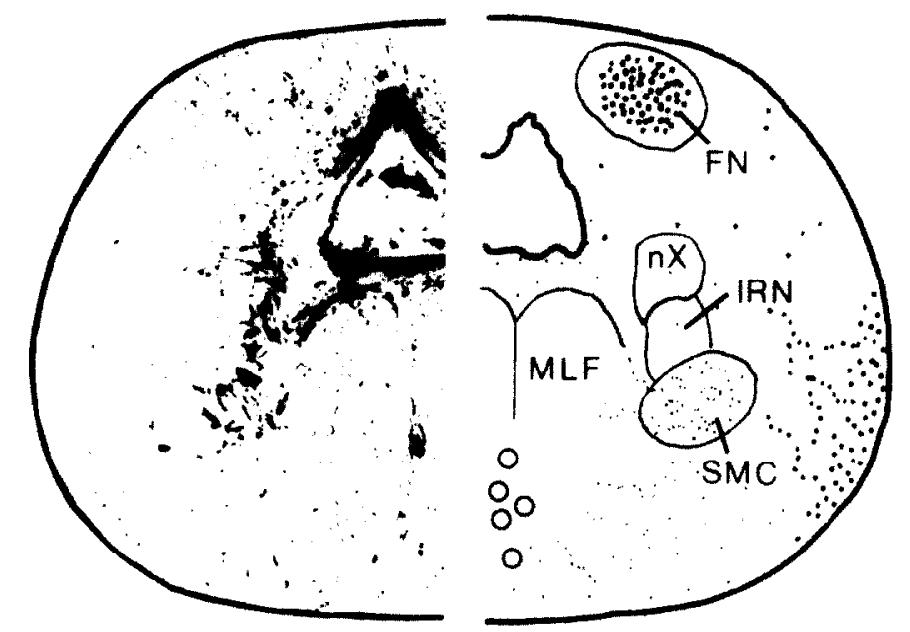

FIG. 2.

\section{C}
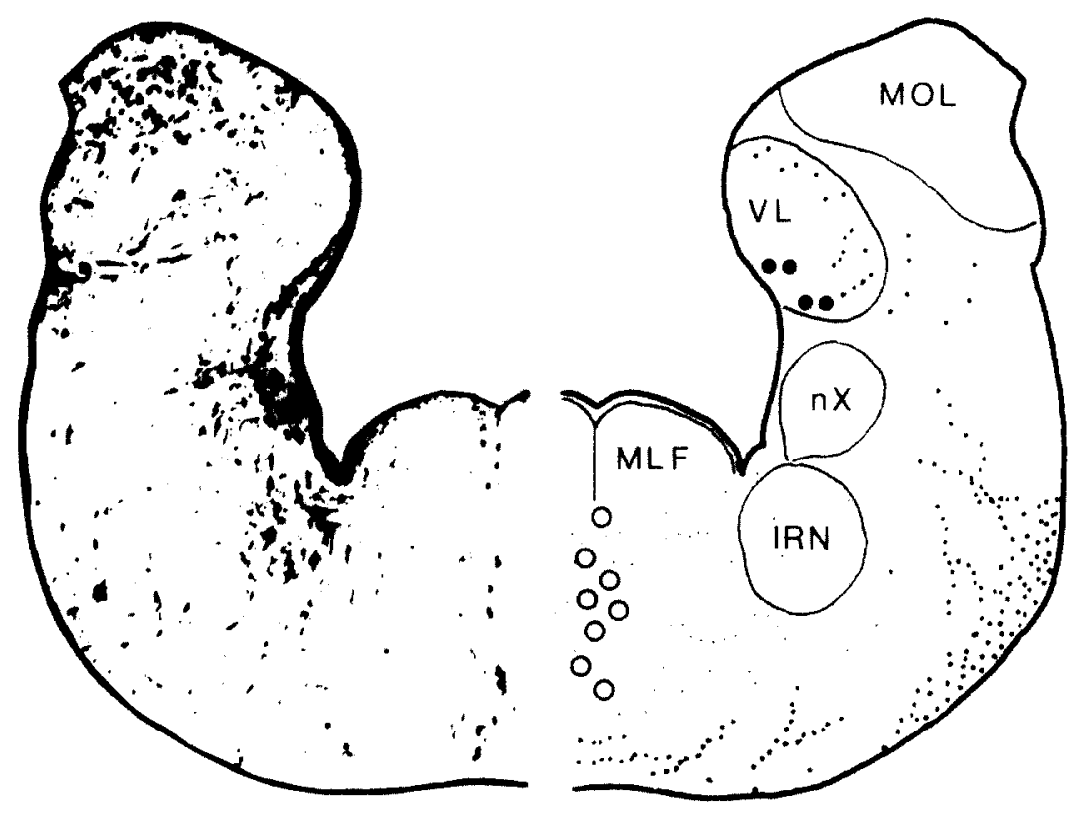

FIGS. 2-7. Series of transverse sections through the brain of Lepisosteus illustrating, on the right side, the distribution of CA-containing cell bodies (full circles) and CA axonal varicosities (large dots), and of 5-HT-containing cell bodies (open circles) and 5-HT axonal varicosities (small dots). In these figures, the left side is a high-contrast photomicrograph of a corresponding transverse section stained with cresyl violet. 

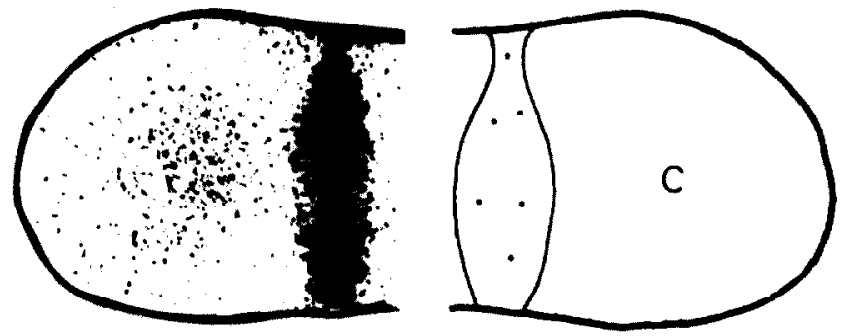

A
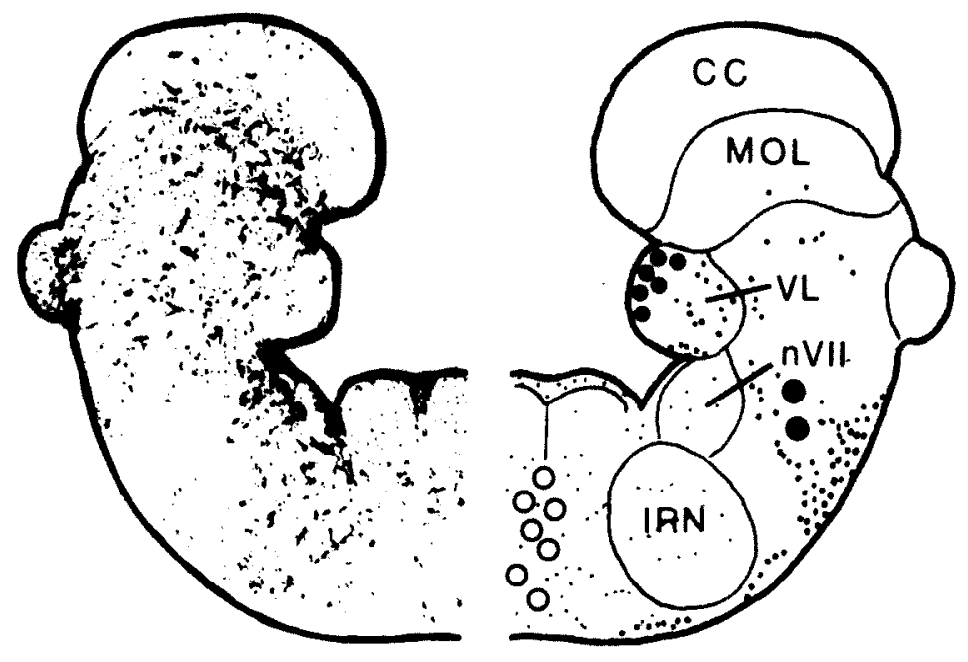

FIG. 3. B

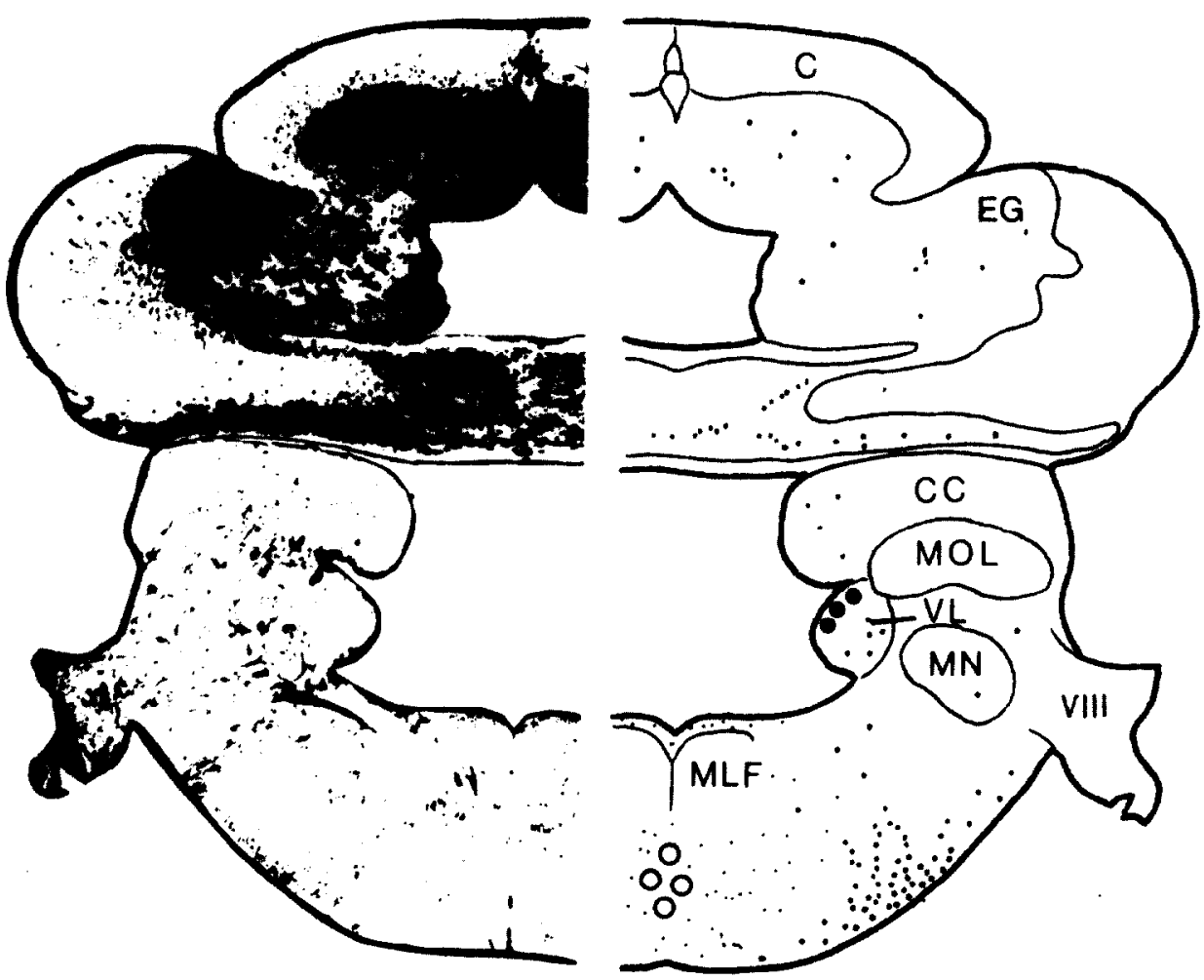




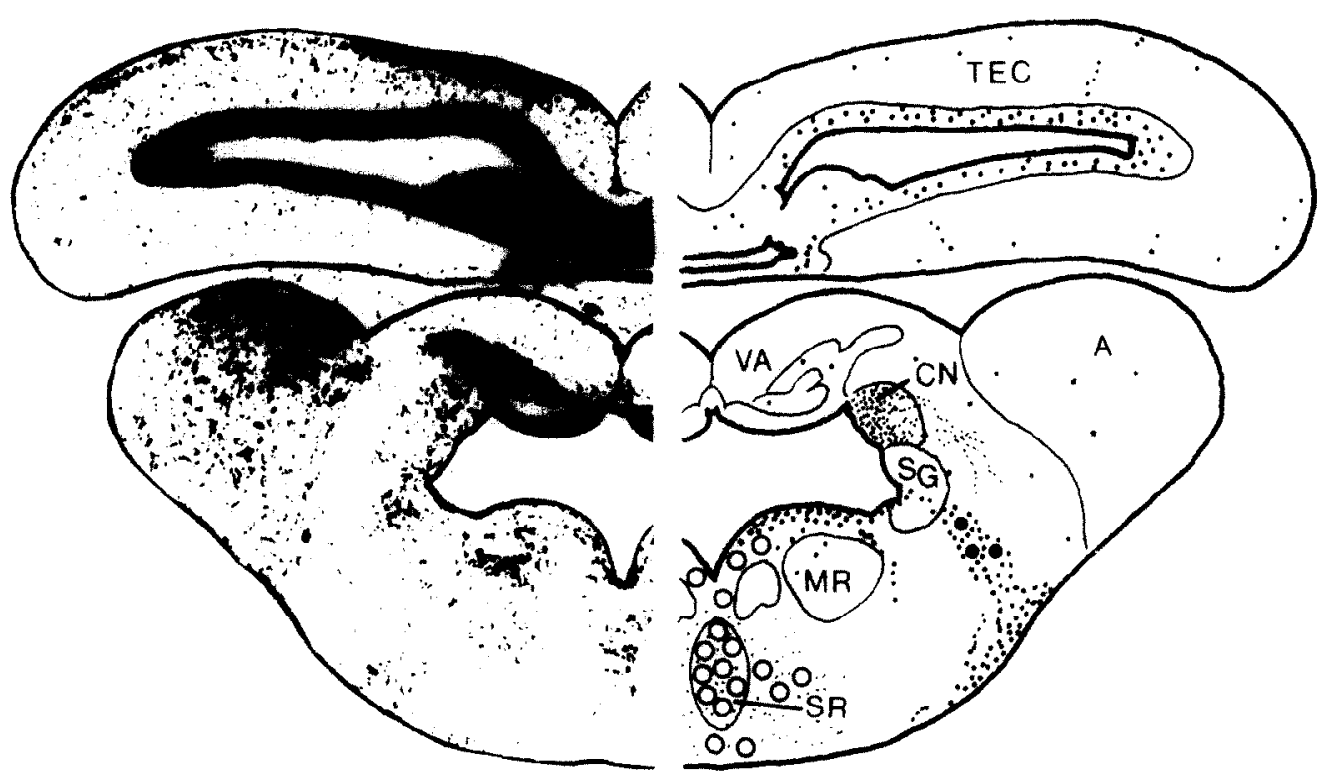

A
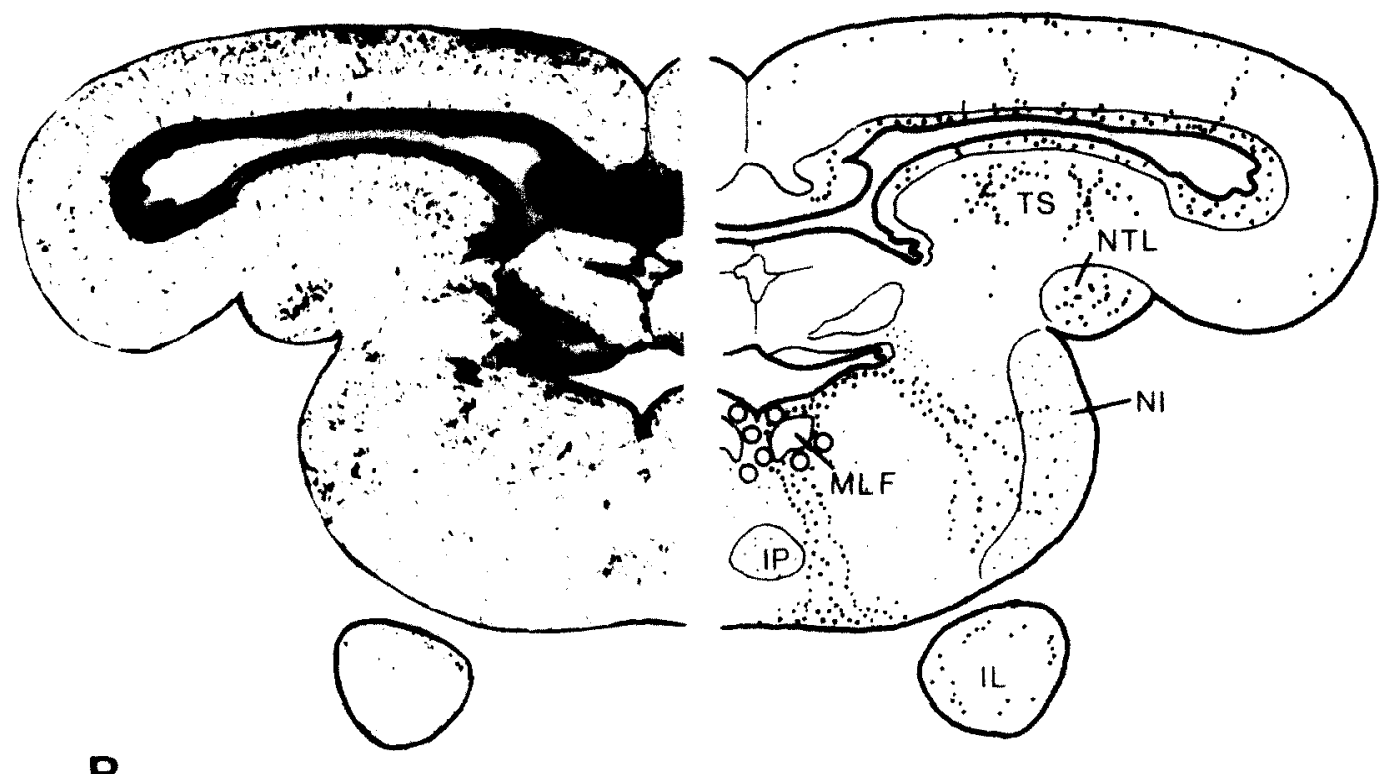

FIG. 4. 

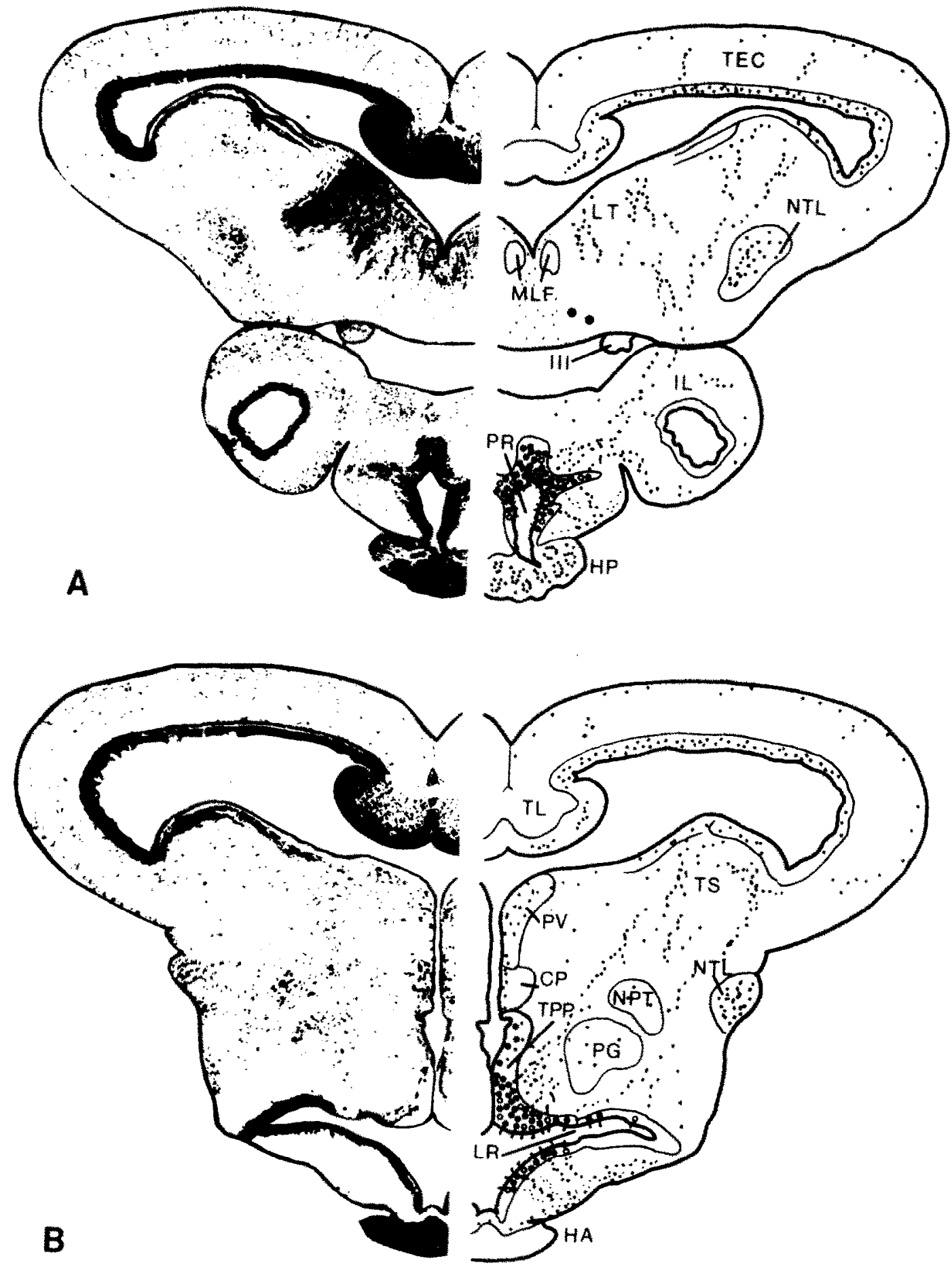

FIG. 5. 


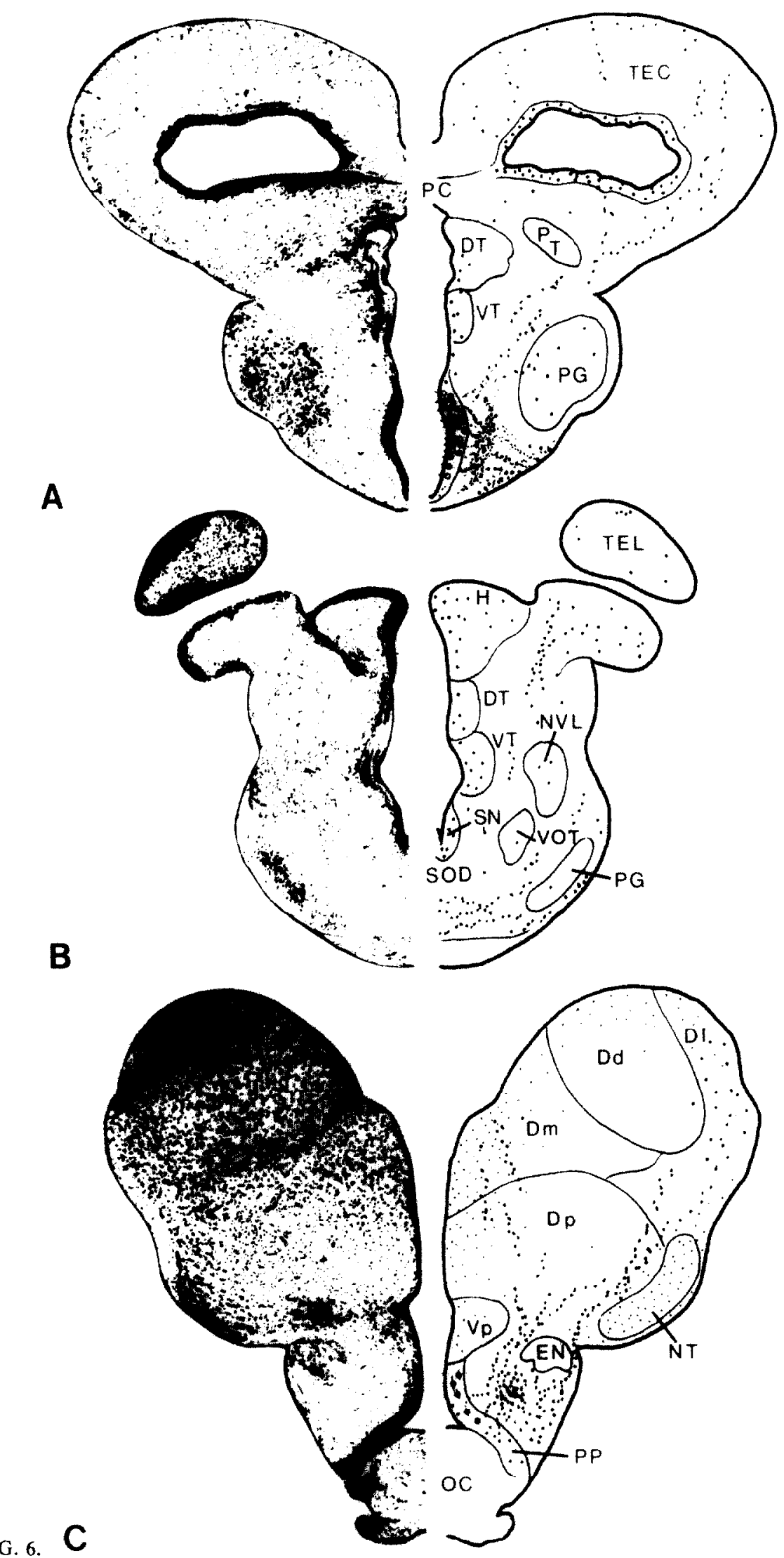




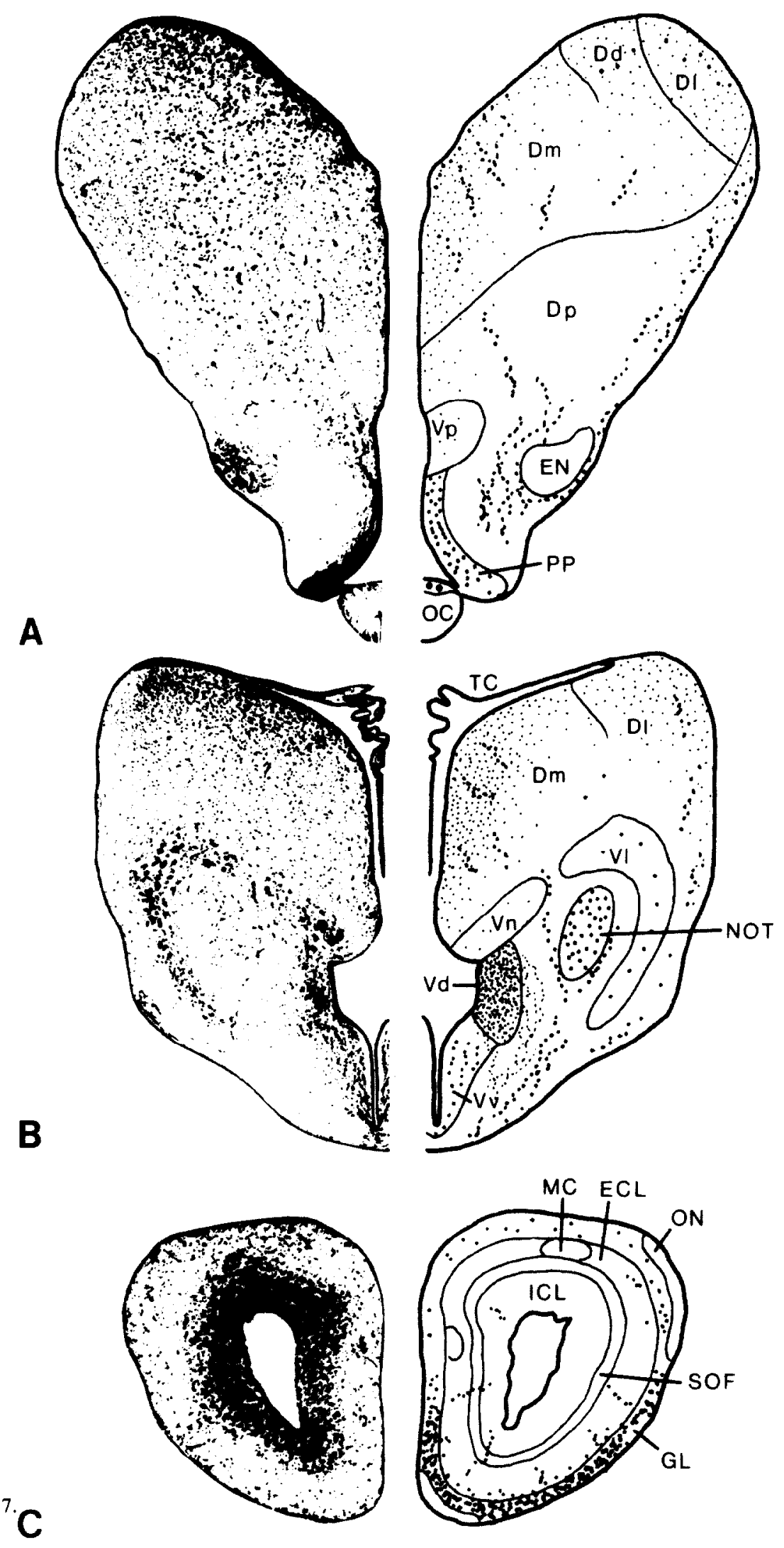



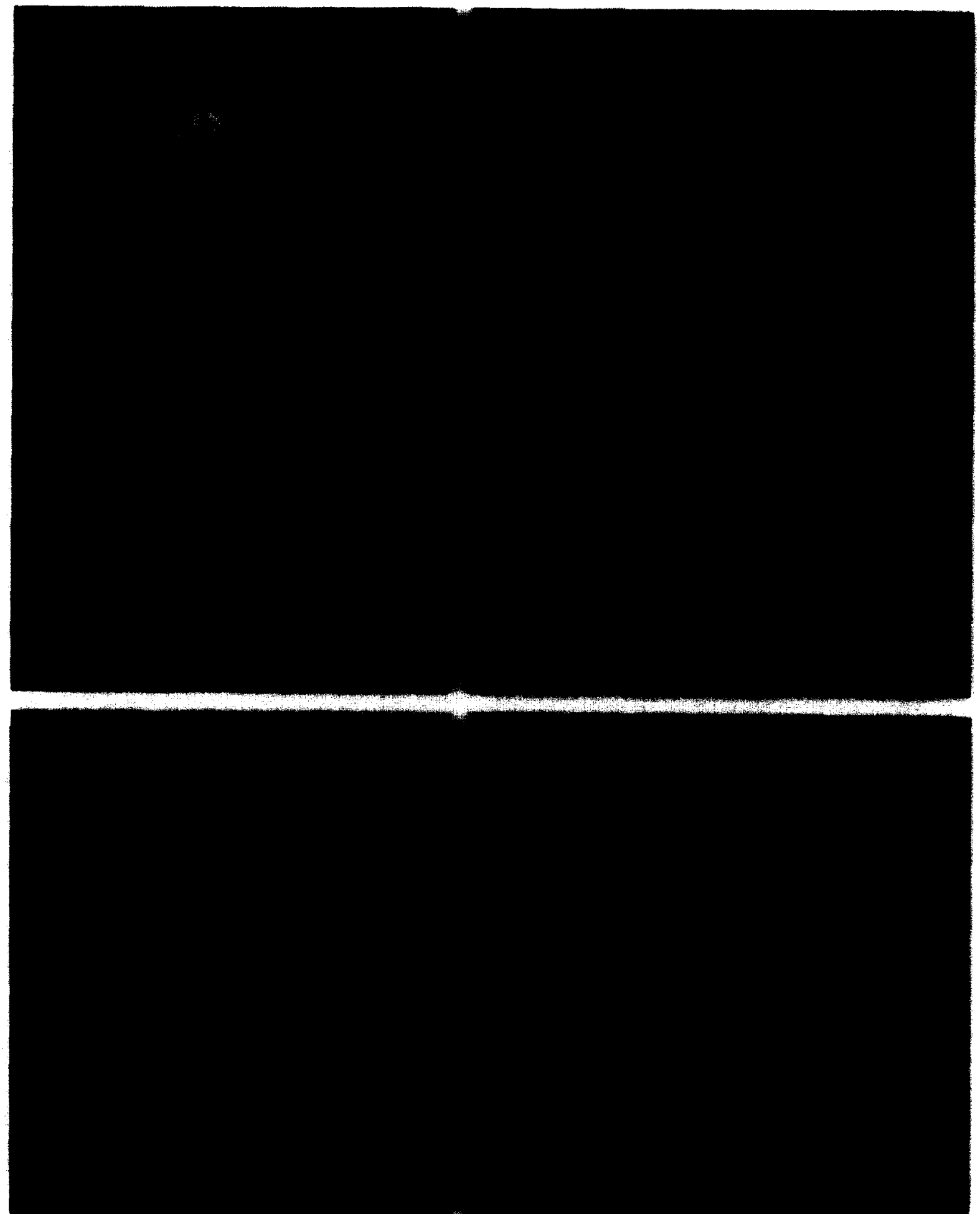

FIG. 8. A-B: Photomicrographs of transverse (A) and horizontal (B) sections through the medullo-spinal junction (see also Fig. 2A) showing numerous CSF-contacting CA cells (arrows in $A$ and all cells in B) located near the lumen (L) of the central canal. Some 5-HT cells (crossed-arrows in A) are seen in-between the medial longitudinal fasciculi (MLF). C-D: Photomicrographs of transverse sections through the upper medulla (see also Fig. 3A) depicting 5-HT cells within the raphe region in-between the MLF (C), and CA cells located in the central portion of the medulla, near the ventricle (VT) (D). Falck-Hillarp method (A, C, D) and SPG procedure $(B)$. 

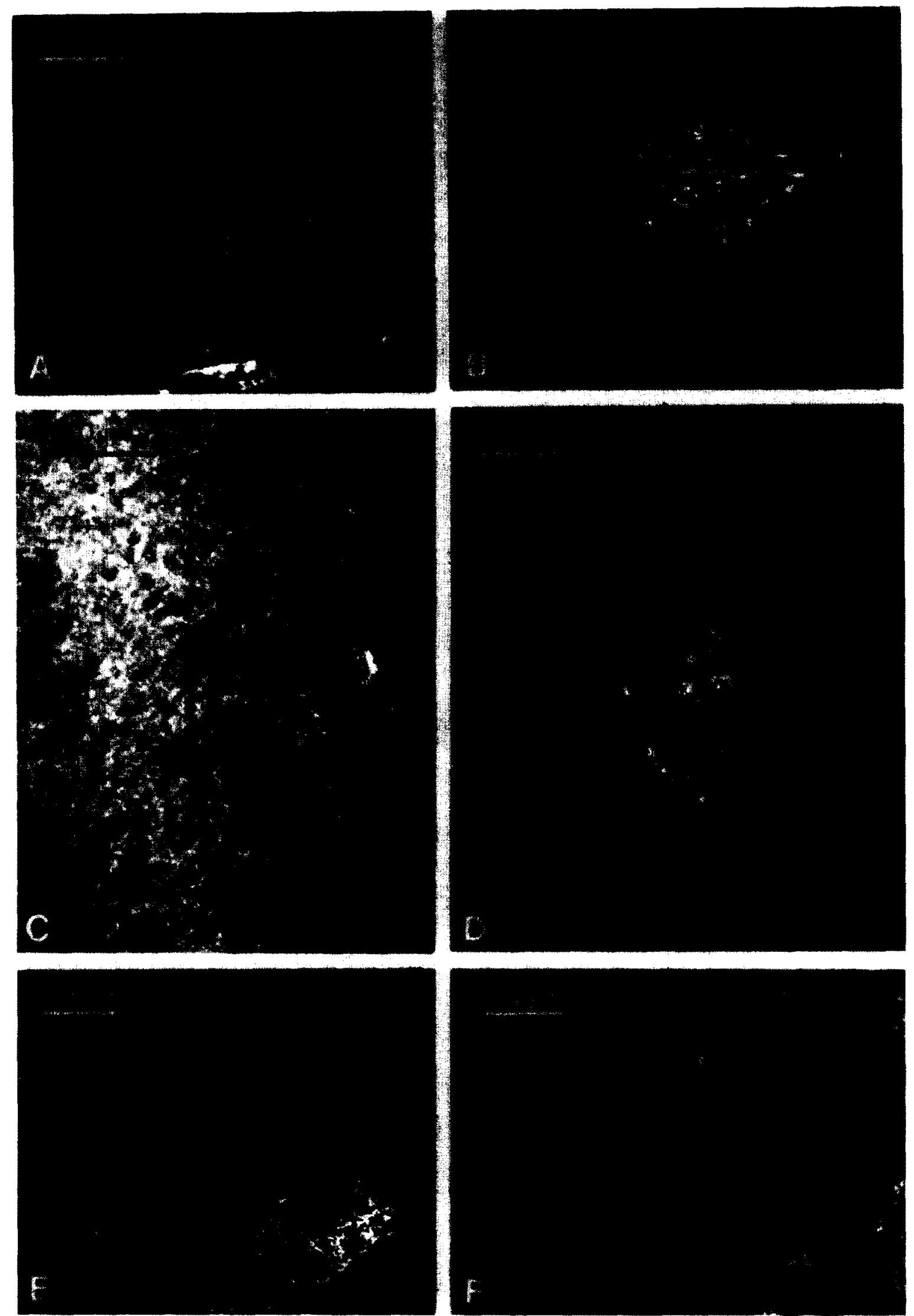

FIG. 9. A-C: Photomicrographs showing numerous 5-HT axonal varicosities present around the interpeduncular nucleus (IP in A) (see also Fig. 4B), within the cerebellar nucleus (B) (see also Fig. 4A), and in the dorsal nucleus of area ventralis telencephali (C) (see also Fig. 7B). D-F: Photomicrographs depicting abundant CA axonal varicosities in the funicular nucleus (D) (see also Fig. 2B), in the nucleus of torus lateralis (E) (see also Fig. 5A), and in the olfactory bulb $(\mathrm{F})$ (see also Fig. 7C). The arrows in $\mathrm{F}$ point to $\mathrm{CA}$ varicose fibers en route to the glomerular layer (GL). Transverse (A, C, D, E) and horizontal (B, F) sections. Falck-Hillarp method (A-E) and SPG procedure (F). 
5-HT types distributed along and partly within various portions of the ependymal wall of the third ventricle. These cells are characteristically provided with a short club-like process protruding directly into the third ventricle. A much thinner and longer ependymofugal process can also be visualized. Rostrocaudally, such CSF-contacting MA cells are first encountered in the middle third of the hypothalamus. There they lie along the small sulcus which divides the hypothalamus into its dorsal and ventral portions (Fig. 6A). As we proceed more caudally into the hypothalamus the number of CSF-contacting MA cells increases, particularly along the dorsal border of the lateral recess (nucleus recessus lateralis of certain authors, see [31]) (Fig. 5B), and around the postcrior recess (Fig. 5A) (nucleus recessus posterioris) where up to ten rows of closely-packed MA cells can be found. The 5-HT cells appear to be less numerous than the CA cells within these various regions of the hypothalamic periventricular gray. It has been roughly estimated that the 5-HT cells represent only about $30-40 \%$ of the total population of CSF-contacting MA cells. However, the 5-HT cells appear to be uniformly scattered among the CA cells and no preferential distribution has been noticed. The numerous CSF-contacting MA cells in the hypothalamus of Lepisosteus contribute to the innervation of various hypothalamic as well as extrahypothalamic structures. First, the thin ependymofugal processes of some of these CA and 5-HT cells can be seen to form dense patches of fluorescent material which often surround blood vessels at the base of the hypothalamus (Figs. 6A, 10A). These numerous patches, which are more or less continuous with one another, appear to consist of a multitude of brightly fluorescent and closely-packed axonal varicosities (Fig. 10A). Secondly, other ependymofugal processes, mainly of the CA type, can be traced as far as the inferior lobe of hypothalamus, laterally, and the torus semicircularis and optic tectum of the midbrain, dorsocaudally (Figs. 5, 6A). The latter projections are particularly well outlined in parasagittal sections prepared according to the SPG method. The same preparations also reveal that some CA fibers arising from CSF-contacting MA cells in the hypothalamus ascend within the lateral zone of the preopticohypothalamic complex to reach the telencephalon. A certain proportion of the CA fibers present in the lateral preopticohypothalamic region can be seen to cross the midline within the supraoptic decussation (Fig. 6B). Also worth noting is the presence of small clusters of fluorescent material dispersed throughout the posterior half of the hypophysis (Fig. 5A). These clusters, which appear to be formed by numerous closely-packed CA varicosities, are particularly abundant along the extensive perivascular system present within the neurointermediate hypophysial complex (see also $[28,31]$ ). In contrast, the anterior half of the hypophysis, comprising the adenohypophysis, is completely devoid of fluorescent material (Fig. 5B).

Small-sized CA cells are also present along the ependymal wall of the preoptic recess, among the non-fluorescent neurons of the magnocellular and parvocellular parts of the periventricular preoptic nucleus (Figs. 6C, 7A). The most rostrally located $\mathrm{CA}$ cells of this group lie just above the rostral pole of the optic chiasm (Fig. 7A). The CA neurons found along the preoptic recess display a fluorescence whose intensity varies from one cell to the other (Fig. 10B). Their processes do not seem to contact directly the CSF of the third ventricle but instead are mostly aligned parallel to the ventricular wall (Fig. 10C). These CA cells are also seen to contribute fibers which appear to ascend toward the telen- cephalon through the lateral preoptic region (Fig. 6C). They may also provide part of the very dense pericellular CA innervation disclosed at the level of the periventricular preoptic nucleus itself (Fig. 7A).

In contrast to the hypothalamus, the thalamus does not contain MA cell bodies and appears relatively poorly innervated by MA axons. A moderately dense CA innervation occurs within the periventricular gray of the thalamus (Figs. $6 A, B)$, whereas only a few, uniformly scattered, $C A$ and 5-HT axonal varicosities are found in other thalamic regions.

\section{Telencephalon (Figs. $6 B, 6 C, 7,9 C, 9 F$ )}

Despite the fact that MA-containing cell bodies are not found within the telencephalon, this portion of the brain nevertheless is densely innervated by MA fibers, particularly 5-HT axons, seemingly originating from the brain stem and hypothalamus. On the one hand, numerous ascending CA fibers can be visualized in the lateral preoptic region (Figs. 6C, 7A). Some of them sweep dorsally around the entopeduncular nucleus to reach the medial (Dm) and lateral (DI) zones of the area dorsalis telencephali where they appear to terminate (Figs. 6C, 7A). However, the majority of the ascending $\mathrm{CA}$ axons continue their rostral course, at the base of the telencephalon to reach the nucleus of the olfactory tract (Fig. 7B) and also the glomerular layer of the olfactory bulb (Figs. 7C, 9F) where they arborize profusely. On the other hand, a multitude of very fine 5-HT axonal varicosities can be visualized within the telencephalon. These varicosities are extremely abundant in the dorsal nucleus of area ventralis telencephali (see Fig. 7B), and moderatley so in the dorsal $(\mathrm{Dm})$ and lateral $(\mathrm{Dl})$ zones of area dorsalis telencephali (Figs. 7A, B). A significant number of 5-HT varicosities occurs also in nucleus taenia (Fig. 6C). The 5-HT innervation of the dorsal nucleus of area ventralis telencephali is one of the densest MA innervations to be observed in the entire brain of Lepisosteus. There, the 5-HT varicosities are very closely-packed and this whole area displays an intense and diffuse yellowish fluorescence (Fig. 10C). Within the dorsal and lateral zones of area dorsalis telencephali the 5-HT varicosities are more abundant near the brain surface and decrease progressively in number as we proceed more deeply into the telencephalic vesicle. Their distribution is more uniform in nucleus taenia.

\section{DISCUSSION}

\section{The 5-HT-Containing Neuronal Systems}

The 5-HT-containing neuronal systems in the brain of Lepisosteus are remarkably well-developed relative to those in teleosts such as the sunfish (Lepomis gibbosus). In lepisosteus the raphe 5-HT neurons form a prominent cell collumn extending rostrocaudally from midbrain to upper spinal cord levels; whereas in Lepomis 5-HT cells are encountered in the raphe region only at caudal midbrain and isthmal levels. Furthermore, the 5-HT neurons at isthmal levels in Lepisosteus are not confined to the raphe region but extend through the lateral portion of the tegmentum. Such lateralization of the 5-HT systems has been noticed in some mammals [18], but is particularly obvious in birds where the 5-HT neurons massively invade the lateral tegmentum and become closely intermingled with the CA neurons of the locus coeruleus and subcoeruleus [11].

Axonal branches of these numerous 5-HT neurons in the hrain stem of Lepisosteus arborize profusely at all levels of 


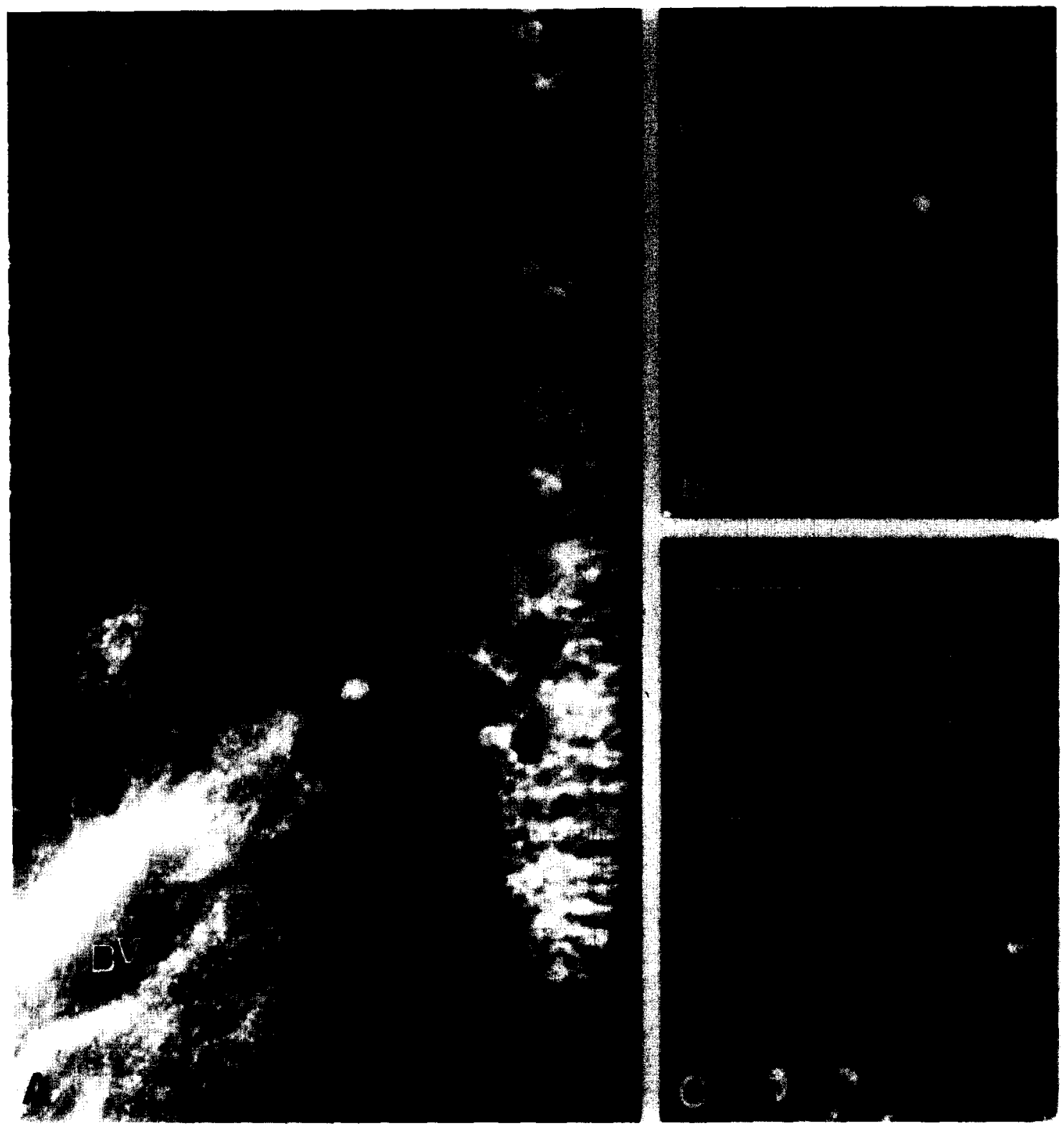

FIG. 10. A: Photomicrograph showing numerous CSF-contacting cells of both CA and 5-HT types bordering the third ventricle at hypothalamic level (see Fig. 6A). Abundant ependymofugal processes arising from some of these cells can be seen to form a dense patch of fluorescent material surrounding a longitudinally-sectioned blood vessel (BV). B-C: Photomicrographs depicting CA cell bodies present within the periventricular preoptic nucleus. Some of these cells display thick varicose processes $(C)$ aligned parallel to the ventricular wall. Horizontal $(A)$ and transverse $(B, C)$ sections. Falck-Hillarp method.

the neuraxis. The structures most densely innervated by 5-HT axons include the spinal motor cells, the so-called cerebellar nucleus, and the dorsal nucleus of area ventralis telencephali.

In mammals, 5-HT is known to exert a potent influence on the activity of spinal motor cells $[2,6]$. This effect is apparently mediated by 5-HT-producing neurons located in nuclei raphe magnus and pallidus of the lower medulla, whose descending axonal processes arborize profusely around the neuronal somata of the spinal motor cells. Our study strongly suggests that a similar condition exists in holostean fishes. In contrast to mammals, however, the
5-HT varicosities around the spinal motor neurons in Lepisosteus arise from the axons of 5-HT-containing neurons whose cell bodies lie directly within the spinal cord, near the lumen of the central canal.

The "cerebellar nucleus"' and the dorsal nucleus of area ventralis telencephali receive by far the heaviest 5-HT innervation in the brain of Lepisosteus. It is difficult to homologize the "cerebellar nucleus" to similarly located structures in other bony fishes. To our knowledge the dense, well-circumbscribed 5-HT innervation in the periventricular gray of the isthmal region in Lepisosteus has not been demonstrated in any of the other vertebrate, and the very 
dense 5-HT innervation of the dorsal nucleus of area ventralis telencephali may also be unique. Such dense 5-HT innervation is not known in the teleost telencephalon which is rather sparsely innervated by $5-\mathrm{HT}$ axons $[27,32]$. In a recent reinterpretation of the organization of the telencephalon of bony fishes, Northcutt and Braford [22] proposed that the dorsal nucleus of area ventralis telencephali in actinopterygians is homologous to part of the septal region in land vertebrates. Similarly the septal region, particularly the medial septal nucleus, has been shown to contain a moderate number of fine 5-HT axonal varicosities in most land vertebrates investigated thus far. The density of the 5-HT innervation disclosed in the area ventralis telencephali in Lepisosteus, however, is far greater than that observed in the septal region in amphibians, reptiles or mammals [26].

The 5-HT systems are also well-developed in the hypothalamus of Lepisosteus where numerous CSF-contacting cells of the 5-HT type are intermingled among cells of the CA type along the wall of the third ventricle and its various recesses. Serotoninergic CSF-contacting cells could not be detected with certainty among the multitude of $\mathrm{CA}$ cells which occurs in the hypothalamus of Lepomis. Although the presence of monoaminergic CSF-contacting cells appears to be one of the most constant features of the MA systems in the hypothalamus of non-mammalian vertebrates, the number of these cells, as well as the relative proportion of CA versus 5 -HT elements, varies significantly among vertebrate groups [24]. In the eel (Anguilla anguilla), microspectrofluorometric methods have demonstrated that about $80 \%$ of the CSF-contacting hypothalamic cells are dopaminergic, and that the remaining cells contain 5-HT or 5-HTP [15]. A similar proportion of CA versus 5-HT CSF-contacting cells has been revealed in the hypothalamus of various other teleosts $[12,31,32]$. In Lepisosteus, the proportion of CSFcontacting cells of the 5-HT type is slightly higher $(30-40 \%)$ than that found in teleosts. In mammals, there appear to be no hypothalamic 5-HT cells in direct contact with the CSF, although the third and lateral ventricles contain a dense supra- and subependymal plexus of 5-HT axons originating chiefly in the dorsal raphe nucleus $[1,29]$. Therefore, it appears that all vertebrates, including mammals, possess 5-HT neurons that form an important informative link between the $\mathrm{CSF}$ and the neural tissue.

\section{The CA-Containing Neuronal Systems}

In the brain of Lepisosteus, the CA-containing neuronal systems are rather poorly developed in comparison to the 5-HT systems. Their organization is similar to that in teleosts, but with some differences $[19,27,32]$.

Among the most striking similarities are (1) the presence of a small number of CA perikarya in the central and dorsal (vagal lobe) regions of the medulla oblogata and (2) the existence of a multitude of small CSF-contacting cells of the CA type within the hypothalamus.

The CA perikarya in the central portion of the medulla in Lepisosteus are probably comparable to the CA cells of the $A_{1}$ and $A_{3}$ groups first described in the rat by Dahlström and Fuxe [8]. In mammals, these CA cells lie around and partly within the lateral reticular nucleus and form the medullary part of the so-called lateral tegmental CA cell system [20]. The CA perikarya in the dorsal (vagal lobe) region of the medulla in Lepisosteus are apparently homologous to the CA cells of the $A_{2}$ group in the rat [8]. In mammals, the CA cells of group $A_{2}$ are located mainly within and around the nucleus of the solitary tract, and in the area postrema where their number varies markedly among different species [16]. This disseminated cell group is also referred to as the dorsal medullary $\mathrm{CA}$ cell system [20]. The presence of CA cells in both the central and dorsal portions of the medulla has been revealed in all vertebrate groups investigated thus far, including amphibians, reptiles, birds, and mammals $[11,25]$; thus, this feature of CA systems appears to be remarkably constant throughout phylogeny.

The abundant CSF-contacting cells of the CA type in the hypothalamus in Lepisosteus are very similar in topographical distribution and morphological characteristics to the hypothalamic CA cells in Lepomis [27] and other teleosts $[15,31]$. This large monoaminergic cell population in the hypothalamus is comparable to the less prominent MA cell group referred to as the paraventricular organ, which is present in the hypothalamus of amphibians, reptiles, and birds, but apparently absent in mammals (see review in [24]). In Lepisosteus, as in Lepomis, numerous ependymofugal processes of these CSF-contacting CA cells give rise to a very dense, patch-like innervation of the basal hypothalamus. Frequently, patches of fluorescent material, consisting of numerous fine, closely packed MA varicosities, are seen surrounding small cappillaries; a situation resembling that found in the external layer of the median eminence of the hypothalamus in mammals [7]. In addition, the use of the glyoxylic acid method has allowed us to visualize other efferent projections from the CSF-contacting CA cells in Lepisosteus. These projections could be traced as far as the telencephalon and the midbrain tegmentum and tectum. Therefore, in addition to their highly probable role at hypothalamic and pituitary levels, the CSF-contacting hypothalamic CA cells may exert a significant effect on numerous brain structures in Lepisosteus and, perhaps, other bony fishes.

The most obvious differences in the organization of the CA systems in Lepisosteus and Lepomis include (1) the presence of CSF-contacting CA cell at upper spinal cord levels in Lepisosteus but not in Lepomis, and (2) only a few small-sized CA cell bodies at isthmal levels in Lepisosteus relative to the well-developed group of large-sized C.A perikaray in the same region in Lepomis.

Although no CSF-contacting CA cells have been revealed at upper spinal cord levels in Lepomis [27] it should be noted that a local system of fluorescent neurons surrounds the central canal along the whole length of the spinal cord in the Lamprey (Lampetra japonica) [17]. In the pike (Esox lucius). a system of intensely fluorescent norepinephrine-containing cells lies among the basal ependyma of the central canal at lower spinal cord levels $[5,30]$. These cells, which are par. ticularly abundant in the region of the urophysis, send varicose axonal processes which terminate on the neurosecretory cells of this structure in the pike. Although the lower segments of the spinal cord in Lepisosteus were not investigated in our study, it can be assumed that the CSF. contacting CA cells disclosed at upper spinal cord levels in the gar are part of a system extending all along the spinal cord similar to that revealed in the pike. It is also worth noting that a small group of CA cells was observed at the medullo-spinal junction in Lepomis; however, these CA cells do not lie within the cervical spinal cord but above it, immediately caudal to the obex of the fourth ventricle. A similarly located group of CA cells, termed the post-obecular CA nucleus, was recently revealed in another teleost. Myoxocephalus scorpius [32].

Unlike the isthmal tegmentum in Lepomis, with its 
numerous large CA cells comparable to the locus coeruleus of land vertebrates [27], the corresponding region in Lepisosteus contains only a few small CA perikarya. Accordingly, the telencephalic vesicle in Lepomis and other teleosts [32] is densely innervated by $\mathrm{CA}$ axons, presumably originating in some part from the isthmal CA neurons, whereas the telencephalon in Lepisosteus except for the olfactory bulb region contains relatively fewer $\mathrm{CA}$ axonal varicosities. In this regard, Lepisosteus is similar to amphibians, who reveal only a very small group of CA cells in the isthmal tegmentum and very few $C A$ axonal varicosities in pallial telencephalic regions [25].

\section{Conclusions}

In the brain of Lepisosteus osseus, a member of the holostean group of actinopterygian fishes, the MA-containing neuronal systems are organized very differently from those reported in teleost brains. Perhaps the most significant difference is that the central 5-HT-containing neuronal systems are remarkably more developed in holosteans than in teleosts, whereas the converse is true for the CA systems. The pattern of MA system organization in the holostean brain is far more similar to that seen in primitive vertebrates, such as cyclostomes-where the 5-HT systems are highly elaborated relative to the CA systems [4]-than it is to the pattern in more advanced fishes such as teleosts. Because actinopterygians form a wide and divergent phylogenetic radiation with a high degree of interspecific variations, many species will have to be investigated to establish the significance of these morphological differences in the organization of central MA systems in holosteans and teleosts.

\section{ACKNOWLEDGEMENTS}

The authors express their sincere gratitude to Mrs. Carole Harvey for skillful technical assistance, and to Mrs. Monique Baron for typing the manuscript. This investigation was supported by grant MT-5781 of the Medical Research Council of Canada (to A. P.) and by grant NIH-EY02485 (to R. G. N.).

\section{REFERENCES}

1. Aghajanian, G. K. and D. W. Gallager. Raphe origin of serotoninergic nerves terminating in the cerebral ventricles. Brain Res. 88: 221-231, 1975.

2. Anden, N. E., M. Jukes and A. Lundberg. Spinal reflexes and monoamines liberation. Nature, Lond. 202: 1222-1223, 1964.

3. Ariëns Kappers, C. V., G. C. Huber and E. C. Crosby. The Comparative Anatomy of the Nervous System of Vertebrates, Including Man. Reprint. New York: Hafner Publishing Company, 1960.

4. Baumgarten, H. G. Biogenic monoamines in the cyclostome and lower vertebrate brain. Prog. Histochem. Cytochem. 4: 1-90, 1972.

5. Baumgarten, H. G., B. Falck and H. Wartenherg. Adrenergic neurons in the spinal cord of the pike (Esox lucius) and their relation to the caudal neurosecretory system. Z. Zellforsch. 107: 479-498, 1970.

6. Bédard, P., H. Barbeau, B. Barbeau and M. Filion. Progressive increase of motor activity induced by 5-HTP in the rat below a complete section of the spinal cord. Brain Res. 169: 393-397, 1979.

7. Björklund, A., R. Y. Moore, A. Nobin and U. Stenevi. The organization of tuberohypophyseal and reticulo-infundibular catecholamine neuron systems in the rat brain. Brain Res. 51: 171-191, 1973.

8. Dahlström, A. and K. Fuxe. Evidence for the existence of monoamine-containing neurons in the central nervous system. I. Demonstration of monoamines in the cell bodies of the brain stem neurons. Acta physiol. scand. 62: Suppl. 232, 1-80, 1964.

9. de la Torre, J. C. Standardization of the sucrose-potassium phosphate-glyoxylic acid histofluorescence method for tissue monoamines. Neurosci. Lett. 17: 339-340, 1980.

10. de la Torre, J. C. and J. W. Surgeon. A methodological approach to rapid and sensitive monoamine histofluorescence using a modified glyoxylic acid technique: the SPG method. Histochemistry 49: 81-93, 1976.

11. Dubé, L. and A. Parent. The monoamine-containing neurons in the avian brain. I. A study of the brain stem of the chicken (Gallus domesticus) by means of fluorescence and acetylcholinesterase histochemistry. J. comp. Neurol. 196: 695-708, 1981.

12. Ekengren, B. Aminergic nuclei in the hypothalamus of the roach (Leuciscus rutilus). Cell Tissue Res. 159: 493-502, 1975.

13. Falck, B., N.-A. Hillarp, G. Thieme and A. Torp. Fluorescence of catecholamines and related compounds condensed with formaldehyde. J. Histochem. Cytochem. 10: 348-354, 1962.
14. Falck, B. and C. Owman. A detailed methodological description of the fluorescence method for cellular demonstration of biogenic monoamines. Acta Univ. lund. 2: 1-23, 1965.

15. Fremberg, M., Th. van Veen and H. G. Hartwig. Formaldehyde-induced fluorescence in the telencephalon and diencephalon of the eel (Anguilla anguilla L.). Cell Tissue Res. 176: $1-22,1977$.

16. Fuxe, K. and C. Owman. Cellular localization of monoamines in the area postrema of certain mammals. J. comp. Neurol. 125: 355-382, 1965.

17. Honma, S. Presence of monoaminergic neurons in the spinal cord and intestine of the lamprey Lampetra japonica. Archvm histol. jap. 32: 383-393, 1970.

18. Léger, L., L. Wiklund, L. Descaries and M. Persson. Description of an indolaminergic cell component in the cat locus coerulus: a fluorescence histochemical and radioautographic study. Brain Res. 168: 43-56, 1979.

19. L'Hermite, A. and G. Lefranc. Recherche sur les voies monoaminergiques de l'encéphale d'Anguilla vulgaris. Archs Anat. microsc. 61: 139-152, 1972.

20. Lindvall, $O$. and $A$. Björklund. Organization of catecholamine neurons in the rat central nervous system. In: Handbook of Psychopharmacology, vol. 9, edited by L. L. Iversen, S. D. Iversen and S. D. Snyder. New York: Plenum, 1978, pp. 139231.

21. Nieuwenhuys, R. The comparative anatomy of the actinopterygian forebrain. J. Hirnforch. 6: 171-192, 1963.

22. Northcutt, R. G. and M. R. Braford, Jr. New observations on the organization and evolution of the telencephalon of actinopterygian fishes. In: Comparative Neurology of the Telencephalon, edited by S. O. E. Ebesson. New York: Plenum, 1980, pp. 41-98.

23. Northcutt, R. G. and A. B. Butler. Projection of the optic tectum in the longnose gar, Lepisosteus osseus. Brain Res. 190: 333-346, 1980.

24. Parent, A. Anatomical organization of monoamine- and acetylcholinesterase-containing neuronal systems in the vertebrate hypothalamus. In: Handbook of the Hypothalamus, vol. 1, edited by P. J. Morgane and J. Panksepp. New York: Marcel Dekker, 1979, pp. 511-554.

25. Parent, A. Monoamine systems of the brain. In: Biology of the Reptilia, vol. 10, edited by C. Gans, R. G. Northcutt and P. Ulinski. London: Academic Press, 1979, pp. 247-285. 
26. Parent, A. The anatomy of serotonin-containing neurons across phylogeny. In: Serotonin Neurotransmission and Behaviour, edited by B. L. Jacobs and A. Gelperin. Cambridge, MA: M.I.T. Press, 1981, pp. 3-34

27. Parent, A., L. Dubé, M. R. Braford, Jr. and R. G. Northcutt. The organization of monoamine-containing neurons in the brain of the sunfish (Lepomis gibbosus) as revealed by fluorescence microscopy. J. comp. Neurol. 182: 495-516, 1978.

28. Polenov, A. L., P. E. Garlov, M. S. Konstantinova and M. A. Belenky. The hypothalamo-hypophysial system in Acipenseridae. II. Adrenergic structures of the hypophysial neurointermediate complex. Z. Zellforsch. 128: 470-481, 1972.
29. Richards, J. G., H. P. Lorez and J. P. Tranzer. Indeolealkylamine nerve terminals in cerebral ventricles: identification by electron microscopy and fluorescence histochemistry. Brain Res. 57: 277-288, 1973.

30. Santer, R. M. Monoaminergic nerves in the central and peripheral nervous systems of fishes. Gen. Pharmac. 8: 157-172, 1977.

31. Terlou, M., B. Ekengren and K. Hiemstra. Localization of monoamines in the forebrain of two salmonid species, with special reference to the hypothalamo-hypophysial system. Cell. Tissue Res. 190: 417-434, 1978.

32. Watson, A. D. H. The distribution of aminergic neurones and their projections in the brain of the teleost. Myoxocephalus scorpius. Cell Tissue Res. 208: 299-312, 1980. 